\title{
Non woven fabric and the difference between Bonded and Needle punched non woven fabrics
}

\author{
Reeta Ghosh \\ Department of Fashion Design/Subharti Institute of fine art and fashion design/Swami Vivekanand Subharti \\ University, India
}

\begin{abstract}
Nonwovens has covered a huge area in industrialization, medical, sports, home furnishing, garments, paper maker etc. but it itself has differences in the way of manufacturing it for various fields. The purpose is to show the applications with their difference in various aspects and to summarize about nonwovens and its categories
\end{abstract}

Keywords: application, bounded non woven fabric, differentiation, needle punched non woven, non woven fabric

\section{INTRODUCTION}

It is known that there was no role of draping fabrics or covering body at the starting age of human life unless the invention of clothing, but yes, it started the covering of body with tree leaf, animal skin, fur, grass to protect it from outer elements. Further other many changes came in making fabrics with the help of weaving, knitting from various animal, vegetable or natural fibers.

When we talk about non woven, it is definitely sure about those materials which are made without weaving process. This was the oldest way of making fabrics and was discovered around 3000-3500 BC back with construction of various animal hair. Non woven fabric consists of fibers which are laid together by various bonding processes instead of weaving and knitting. It can be laid parallel, cross wise or randomly with different applications of adhesive or thermoplastic fibers and under application of heat and pressure, hence non woven-s can be indicated as a fabric made with a web like finish with various applications of adhesive under various heat and pressure.

\section{HISTORY}

History says that making felts, there is a big role of SAINT FEUTRE of CEAN, FRANCE, the patron saint of the felt industry who always put wool fibers in his sandals for his long walking trips, so that he could feel comfortable while walk, apparently it was found that the fibers was formed in to a matted layer because of foot pressure and of course today felt is made from wool with or without admixture of different other animal fibers, vegetable fibers or manmade fibers. Definitely to get the absolute goal of nonwoven manufacturing should have art of choosing the right fiber to combing with the right application of binder and the efficient process for it. In 1965, USA developed new principles and the term "Nonwoven fabrics", which was applied to new modern techniques to innate new other experimental fabrics of nonwoven.

The classic example of nonwoven is felt, either it is wool felt or fur felt, where wool felt comprises of the combination of at least one half of wool fiber with kapok, rayon etc. The short staple fibers are used, the felt is degraded "but the finer the grade of staple used, the stronger the felt." Wool felt's shrink property can be controlled by blending it with acetate, nylon, and acrylic fibers, and about fur felts, such short fibers like rabbit, muskrat or beaver are blended.

\section{MANUFACTURING PROCESS OF NONWOVEN FABRICS}

Virtually all the types of fibers, either it is natural, vegetable or manmade fiber, can be use for manufacturing nonwovens but since it always has to achieve some specific requirements, the fiber choice with the appropriate application of bonding becomes essential. This can be achieved by comparing the requirements to be met together with their obtained results from individual fiber. The rapid uses of fibers which are in greatest volume in industries are cotton, rayon, acetate, nylon, wool including with increasingly usage of synthetic fibers like polyester, acrylics. The below table 1 shows the resultant properties of various fiber blending:-

\section{FIGURES AND TABLES}

Table 1

\begin{tabular}{|l|l|l|}
\hline FIBERS & \multicolumn{2}{|c|}{ RESULTANT PROPERTY } \\
\hline & POSITIVE & NEGATIVE \\
\hline POLYESTER & Good recovery & High pilling tendency \\
\hline
\end{tabular}


Non woven fabric and the difference between Bonded and Needle punched non woven fabrics

\begin{tabular}{|c|c|c|}
\hline & Good heat setting property & Formulation of static charge \\
\hline & High elasticity & \\
\hline & Good drape & \\
\hline & High wet strength & \\
\hline \multirow{6}{*}{ ACETATE } & Good handle & Low wet strength \\
\hline & No pilling & Low abrasion resistance \\
\hline & Good recovery & Low softening point \\
\hline & Good drape & \\
\hline & Easy bonding & \\
\hline & Low price & \\
\hline \multirow[t]{6}{*}{ POLYAMIDE } & Good wet strength & Bad handle \\
\hline & Good resistance to soiling & Bad light fastness \\
\hline & Quick drying & High pilling tendency \\
\hline & Good chemical resistance & High price \\
\hline & Good elasticity & \\
\hline & Good pocessability & \\
\hline \multirow[t]{7}{*}{ COTTON } & Good abrasion resistance & No elastic recovery \\
\hline & Good bulk & Low resistance to soiling \\
\hline & High wet strength & Low uniform of fiber \\
\hline & Soft hand & \\
\hline & Easy bonding & \\
\hline & Excellent absorption power & \\
\hline & Low price & \\
\hline \multirow[t]{5}{*}{ WOOL } & Good bulk & Tendency to pilling \\
\hline & High elasticity & Low abrasion resistance \\
\hline & Soft warm handle & High shrinkage \\
\hline & Quick recovery & Low strength \\
\hline & Good absorption power & Unstable price \\
\hline \multirow[t]{6}{*}{ VISCOSE FILAMENT } & Good strength & Low wet strength \\
\hline & High bulk & Low abrasion resistance \\
\hline & Good drape & Slow drying \\
\hline & High pilling & Hard needle \\
\hline & Easy cleaning & \\
\hline & Low price & \\
\hline & & \\
\hline & & \\
\hline
\end{tabular}

4.1 The manufacturing vary with the fiber methods of laying fibers and use of bonding agent, such as the staple fiber ranges from $1 / 2$ to 6 inches $(2$ to $150 \mathrm{~mm})$ in length or the manmade fiber which is generally

1.5 to 6 denier or some other industrial purpose. The range of fiber may vary. The fibers are processed then through opening, conditioning and blending operations, and then layers of fiber webs are formed accomplished with fiber friction heat adhesion application of bonding agent. Nonwoven fabric bonding can be defined as:

1. Mechanical bonding,

2. Chemical bonding and

3. Thermal bonding

4. Bonding of spun laid webs

A bonding agent works as glue, as it binds the fiber laid web firmly together to make bonded nonwoven fabric. There are several methods of using bonding agents according to the characteristics of required fabric quality. As German standard committee describes "Fabrics made from a combination of fibers and bonding agent is defined as a nonwoven bonded fabric." Whereas needle punching fabrics are produced when spiny needles are pushed together and through a fibrous cross laid web forcing some fibers through the web, where they remain, when the needles are withdrawn. The requirement of a fabric determines the type of bonding agent which executes the characteristic features of nonwoven fabrics, such as

1. Strength

2. Drapeability

3. Elasticity

4. Resistance to chemicals

5. Air, Oxygen

6. Light

7. Heat

8. Hydrophilic or Hydrophobic

9. Flame resistance etc. 
4.2 We are classifying the difference between Bonded and Needle punched nonwoven fabrics in various aspects:

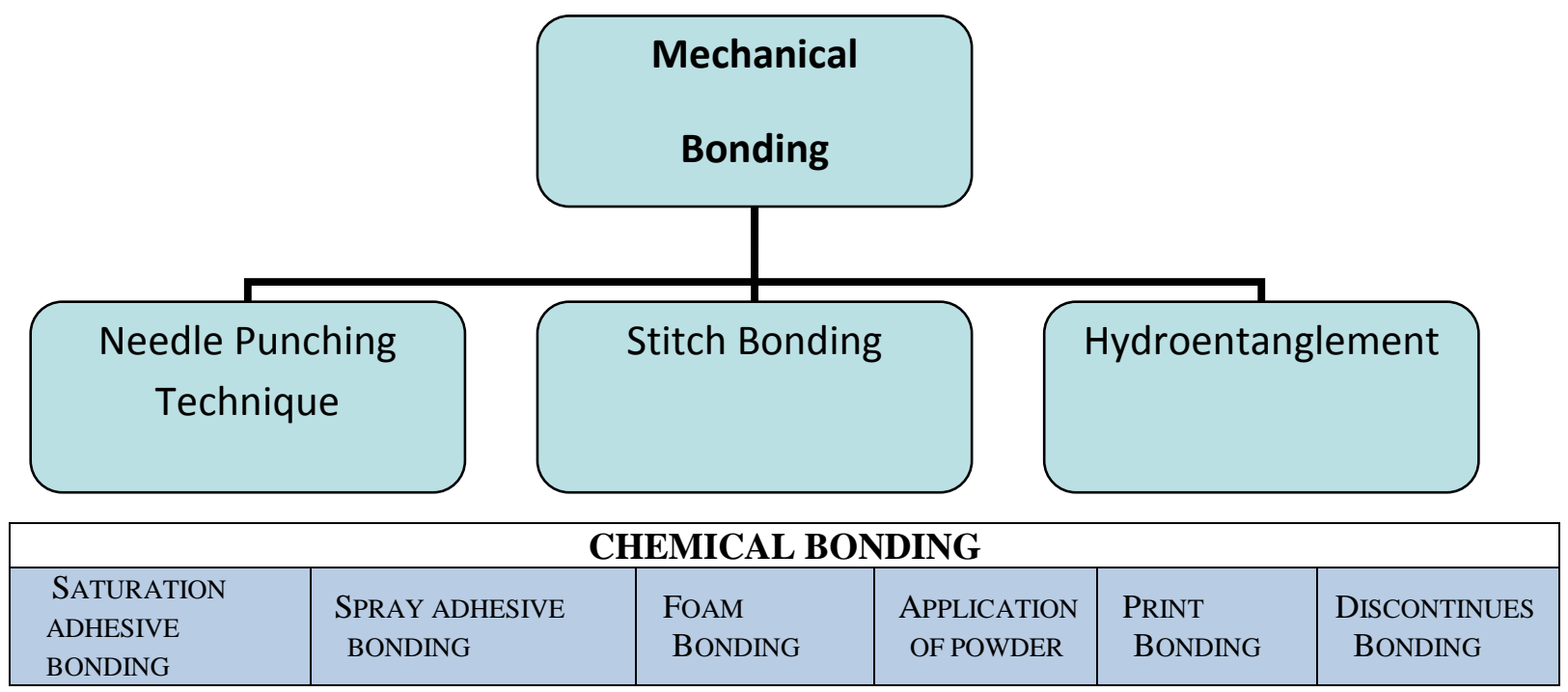

\begin{tabular}{|c|c|c|c|c|}
\hline \multicolumn{5}{|c|}{ THERMAL BONDING } \\
\hline $\begin{array}{l}\text { HOT } \\
\text { CALENDARING }\end{array}$ & $\begin{array}{l}\text { BELT } \\
\text { CALENDARING }\end{array}$ & $\begin{array}{l}\text { THROUGH AIR } \\
\text { THERMAL BONDING }\end{array}$ & ULTRASONIC BONDING & RADIANT HEAT BONDING \\
\hline
\end{tabular}

\begin{tabular}{|l|l|}
\hline \multicolumn{1}{|c|}{ BONDED NONWOVEN FABRICS } & \multicolumn{1}{c|}{ NEEDLE PUNCHED NONWOVEN FABRICS } \\
\hline $\begin{array}{l}\text { Bonded nonwoven fabric can be produce through wet bonding, dry } \\
\text { bonding and spun bonding }\end{array}$ & $\begin{array}{l}\text { Needle punching nonwovens are produced by using triangle needles } \\
\text { punching directly in the web. }\end{array}$ \\
\hline $\begin{array}{l}\text { In this process fiber webs are laid together in layered form and then } \\
\text { they are bonded through chemicals and heat temperature. }\end{array}$ & $\begin{array}{l}\text { Needle punching nonwoven fabrics are processed through needle } \\
\text { punching into web to make the fibers directly tangled with each } \\
\text { other. }\end{array}$ \\
\hline $\begin{array}{l}\text { The layers of web are controlled by the specification of fabric } \\
\text { quality required. }\end{array}$ & $\begin{array}{l}\text { The specific fabric quality maintains the density, intensity and } \\
\text { number of needles. }\end{array}$ \\
\hline $\begin{array}{l}\text { These fabrics are made by chemical or adhesive bonding, hence } \\
\text { poor or low ventilation. }\end{array}$ & Needle punched nonwovens has good ventilation. \\
\hline $\begin{array}{l}\text { Bonded nonwoven fabric plant needs various machinery and } \\
\text { different process equipments as compare to needle punched } \\
\text { nonwovens. }\end{array}$ & $\begin{array}{l}\text { Needle punched nonwoven plants need a nominal number of } \\
\text { machinery and equipments }\end{array}$ \\
\hline $\begin{array}{l}\text { APPLICATIONS: Automotive, civil engineering, sanitary and } \\
\text { medical packaging etc }\end{array}$ & $\begin{array}{l}\text { APPLICATIONS: Tennis court surfaces, space shuttle exterior tiles, } \\
\text { shoe felts, blankets, filters, insulator, fiber glass, insulation felts, } \\
\text { wall coverings, tennis ball covers, interlinings, paper maker felts etc. }\end{array}$ \\
\hline
\end{tabular}

\section{CONCLUSION}

The above differentiation and summarized knowledge about nonwovens shows the applications availability in such a wide area of industries and our day to day life, sometimes we don't even notice about it but yet it is a big part of human life with variety of applications in various fields, hence it can be viewed that in a similarity of same breed of nonwovens, there are still so many differentiations between bonded and needle punched nonwoven fabrics.

\section{REFERENCES}

[1] Bernard P. Corbman - Textiles Fiber to Fabric- sixth edition textlnfo.files.wordpress.com/2011/10/nonwoven-fabrics1.pdf

[2] Term" Nonwoven" http://www.textileschool.com/articles/431/non-woven-fabrics, textlnfo.files.wordpress.com/2011/10/nonwovenfabrics $1 . p d f$

[3] Table 1 (textlnfo.files.wordpress.com/2011/10/nonwoven-fabrics1.pdf)

[4] Bonded nonwovens applications- www.nonwoven-material.cn/spunbond-nonwoven/what-is- spunbon.asp? $\mathrm{m}=\mathrm{k}$

[5] Needle punched nonwoven applications- http://www.engr.utk.edu/mse/Textiles/Needle\%20Punched\%20Nonwovens.htm 